\title{
Discovery in the Linnaean collection of type- material of insects described by Johann Reinhold Forster, with notes on the Hymenoptera
}

\author{
M. C. DAY AND M. G. FITTON \\ Department of Entomology, British Museum (Natural History), \\ Cromwell Road, London SW7 5BD
}

Accepted for publication September 1976

Type-material of 100 insect species described by J. R. Forster has always been thought lost. We present evidence that syntypic specimens of some of these species were sent by Forster to Linnaeus in 1772. Specimens of at least 27 species survive in the Linnaean collection now in Burlington House, and are listed. The identity of each of the 18 species of Hymenoptera described by Forster is examined in detail, particularly the nine represented by specimens. Lectotypes are designated for two species; four new synonymies and two new combinations are established; and three names remain nomina dubia within their genera.

\section{CONTENTS}

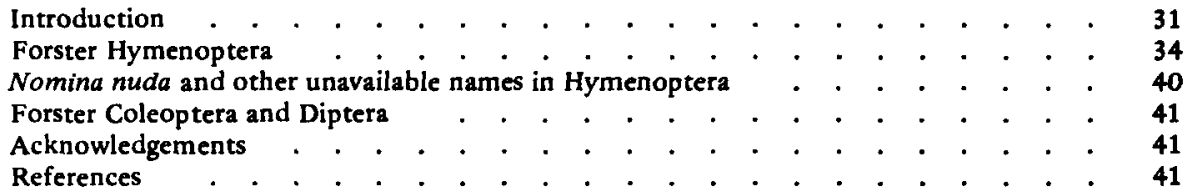

\section{INTRODUCTION}

Johann Reinhold Forster was born in Polish Prussia in 1729, descendant of an English family that emigrated during the reign of Charles I. He studied at Berlin and Halle, and in 1767 after a period spent in Russia, accepted a teaching post at the Dissenters' Academy at Warrington in Lancashire, England (Hoare, 1971; 1976a,b). As a result of "three years assiduous collecting in the neighbourhood of Warrington" he published, in 1770, A catalogue of British insects. Species were identified according to Linnaeus, but the catalogue included several new names of Hymenoptera, and of many other insects, which were clearly marked "NS". However, as published, they are mostly nomina nuda. In 1771, he published $A$ catalogue of the animals of North America, which included hints on the collection and preservation of specimens. His aim was to encourage residents of the British colonies in the New World "to search, 
and to transmit to their friends in England, the productions of their several provinces". He also included in this catalogue names of new species, indicated by the letters "NS", and sometimes with a reference to the collection in which material of these new taxa might be found. Three species of Hymenoptera were listed as new; the abbreviation "Mus. Bl." indicates that the material is from "a most select and numerous Collection of American Animals, belonging to a lady in Lancashire". No more precise identification of the lady is given; but it is probable that she was Anna Blackburne (Shillito, 1976).

Later in 1771, Forster published his Novae Species Insectorum:Centuria I. One hundred species of various orders from England, Europe, China and America were described as new; many of these were valid descriptions of species referred to in his two catalogues. Eighteen of the species are Hymenoptera.

Forster was subsequently to participate as a naturalist on Cook's second circumnavigation of the Globe. His Observations made during a voyage round the world was published in 1778 , but shortly after, following disagreement with the Government about the publication of accounts of the voyage, he accepted the Professorship of Natural History at Halle. He lived and worked there until his death in 1798, publishing numerous works, but describing no further new species of insects.

Many of Forster's species names are in current use, recognized solely from his descriptions, which were of unusual detail for the period. No authentic specimens were generally known subsequently to have been examined, and it has been supposed that the material of his own collection (and, presumably, also that of the "Lady in Lancashire") was totally lost. Van der Vecht (1959) re-examined the descriptions of the nine Aculeate Hymenoptera described by Forster, and made tentative assignments of the six names not currently in use. Fitton (1976) dealt with the Ichneumonidae, referring to previous interpretations; type-material was presumed lost.

In the course of curating the Linnaean Ichneumonidae, housed in London by the Linnean Society at Burlington House, Piccadilly, one of us (M.G.F.) recognized that certain ichneumonid specimens bore labels with the names of Forster species. Further, these labels were in a hand other than those of Linnaeus or J. E. Smith. More detailed examination of the collection brought to light specimens of nine species of Hymenoptera, bearing labels in the same unfamiliar hand, all of these names published by Forster in 1771. In each case, the agreement of these specimens with Forster's descriptions was excellent. In addition, a bee was found bearing a Forster nomen nudum from the Catalogue of British insects, 1770; the label, "25. Pennipes NS.", was cut from Forster's original publication. The probability that this material consisted of original Forster specimens appeared strong. The Linnaean correspondence and collections of other orders of insects were thus examined, in order to assess the authenticity of these specimens.

The Linnaean correspondence includes several letters written by Forster to Linnaeus. The first, dated March 24th, 1772, consists of an introductory paragraph of the kind usual for a first letter from disciple to mentor. The second paragraph begged acceptance of a copy of the authors Novae Species Insectorum and his other works for the master's interest and comment. It appears that Forster had long contemplated writing to Linnaeus, but was 
finally prompted to do so by a letter from Linnaeus to Gahn, in which Linnaeus had expressed interest in seeing a copy of Forster's Centuria.

A second letter, dated June 18th 1772, appears to have been in response to a reply from Linnaeus; tantalisingly, no copy of any such reply exists. Forster's second sentence stated that he was preparing to send specimens to Linnaeus. He then informed Linnaeus of the projected circumnavigation of the globe in which he was to participate. Towards the end of the second page, he wrote as follows:

"Intra parvam pyxidem, que Tibi brevi tradetue, sunt plures quam CL species Insectorum, pleraque novae, partim in Centuria mea descriptae, partim descriptae in paucis plagulis, quas huic litterae junxi; \& quae partim in $2^{\text {da }}$ Centuria mea destinaveram publici ..."

Amongst the Linnaean papers is a manuscript in Forster's hand describing 29 further species of insects. Doubtless this is the "paucis plagulis quas huic litterae junxi". In the insect collections are specimens of seven species of various orders which bear labels in the same handwriting, and which agree perfectly with Forster's descriptions in that manuscript of the species referred to by those names. Many of these labels terminate with the letters "NS" or "NSF", as do some of the labels on the specimens of published species. The handwriting on the labels of both published and manuscript species, of the manuscript, and of the Forster letters, appears consistently to be that of one individual. We are thus in no doubt that these specimens are original Forster specimens, sent to Linnaeus by Forster himself, and returned to England unrecognized as part of the Linnaean collection. Unfortunately, there are no annotations in Linnaeus's copies of Forster's works to indicate which species may have been received from Forster. However, some of Forster's manuscript names, with diagnoses, appear as annotations in Linnaeus's interleaved copy of the 12th edition of the Systema Naturae. Further, Forster himself appears to have made diverse annotations in the copies of his works sent to Linnaeus, including the addition of some of the twenty-nine new species described in the manuscript.

The Linnaean material of other orders also contains Forster-labelled specimens which correspond with his published descriptions. We have not searched with great thoroughness, but those taxa represented are listed below. Those specialists in other orders who wish to identify Forster material should note that, in addition to bearing characteristic labels, many of the specimens are mounted on long brass pins, which have been cut short rather crudely either above or below the specimens, or in two cases, bent over.

Kirby (1802) in his Monographia Apum Angliae, p. 275, in discussion under Apis bicornis, states: "Forster, in his catalogue of English Insects, has made two species out of the male; our $\alpha$ he calls $A$. vernalis, under which name he sent it to Linnaeus, and it is still in the cabinet". We have unfortunately failed to locate this specimen. On p. 305, he refers to a Linnaeus manuscript species "which he received from Forster". However, he neither recognized the specimen bearing this name in the Linnaean collection, nor the specimen labelled Apis albifrons by Forster.

These references are of interest because it is clear that Kirby was aware of those publications of Forster's that included bees; that he was familiar with the 
manuscript annotations in the Linnaean copy of Systema Naturae; and was aware that at least one Forster specimen had been sent to Linnaeus, and still existed in the Linnaean collection. However, although he studied many contemporary collections, and had definite ideas about identification by comparison with original material, he makes no mention of any Forster collection extant. He did coincidentally present descriptions of two Forster manuscript names; these are dealt with in the succeeding taxonomic part of this paper.

Kirby was in close contact with Marsham, who in 1802 published Coleoptera Britannica. On pp. xxiii-xxiv of the introduction, Marsham referred to Forster material in conjunction with the collections of the British Museum. It is not wholly clear to us whether or not Marsham saw actual Forster specimens; or if he did, whether they remained the property of the BM. Certainly, no such material can be located today. It would seem probable that Forster would have taken as much as possible of his possessions with him to Halle. Whether he took specimens is not known to us. It is possible that unrecognized Forster material may be found in Halle.

We conclude that the material Forster described, which was received from diverse sources, would originally have been located in various collections. In particular, we know certainly that two benefactors in Lancashire had some specimens, and Forster himself had a collection. In his British catalogue he annotated certain species with a letter " $d$ ", indicating that he had sufficient specimens to warrant exchange with other interested collectors. However, for one of the ichneumonid species described in the Centuria he specifically stated only one specimen. It seems then that Forster would not have been able to dispose as he pleased of all material described. Nevertheless, he would clearly have had duplicates of many of his species, particularly those collected by himself. We presume that he would have sent to Linnaeus only duplicate specimens available to him from his own collection. Even so, he sent material of more than 150 described and manuscript species to Linnaeus, many of them exotic. Whether he also left specimens which finally were deposited in the British Museum, is not clear.

For each of the Forster species represented in Burlington House by a single specimen, there is thus strong presumptive evidence that it is the single surviving syntype of an original series. However, in the absence of positive evidence to the contrary, we believe it more prudent to regard each such specimen as a holotype, and we have accordingly labelled them as such. English specimens probably originate from localities near Warrington.

The identities of the Forster species of Hymenoptera represented in the Linnaean collection are discussed below. In addition, we have thought it worthwhile to discuss those species not so represented, since it is clear that his descriptions of those species for which material is available were remarkably accurate. Species are considered in sequence as published in the Centuria.

77.

FORSTER HYMENOPTERA

Mesopolobus sericeus (Forster) comb. nov. nomen dubium [Pteromalidae]

Cynips species 12. Geoffroy, 1762: 301. 
Cynips sericeus Forster, 1770: 14. Type-material not located, presumed lost. FRANCE, Paris.

Cynips sericea Forster; Forster, 1771b: 77.

Cynips minutus Geoffroy in Fourcroy, 1785: 383. Type-material not located, presumed lost. FRANCE, Paris. Synonymy by Dalla Torre, 1898: 421.

Diplolepis sericea (Forster); Dalla Torre, 1898: 421.

No type material of these taxa is known to exist; both Forster's and Geoffroy's names refer to Geoffroy's original description and are thus potentially objective synonyms. We consider Forster's brief reference (1770) to Geoffroy to constitute an indication under Article 16 (a) (i) of the International code of zoological nomenclature, and thus to be sufficient to make his name available from that date.

With the benefit of modern knowledge of the insect communities associated with oak galls, it is possible to postulate that Geoffroy had material of the gall of Andricus ostreus (Hartig). If so, it is most likely that his chalcid would have been the species currently known as Mesopolobus fasciiventris Westwood. However, some doubt remains and we think it best to leave the name as a nomen dubium in Mesopolobus for the present.

$\mathrm{Dr} Z$. Boucek spent much time discussing the possible identity of this species with us.

78.

Arge cyanocrocea (Forster) [Argidae]

Tenthredo cyanocrocea Forster, 1770: 13. Nomen nudum.

Tenthredo cyanocrocea Forster, 1771b: 78. LECTOTYPE ㅇ, ENGLAND

(Linn. Soc., London), here designated by J. Quinlan [examined] .

Arge cyaneocrocea [sic] (Forster); Konow, 1905: 18.

There are two female specimens in the Linnaean collection on identical pins. One, labelled "cyano-crocea" [in Forster's handwriting] and "caerulescens Fab. 3. 108" [in J. E. Smith's handwriting], has been selected and labelled by Mr J. Quinlan as lectotype of Tenthredo cyanocrocea. This species has always been correctly interpreted.

79.

Tenthredo arcuata Forster [Tenthredinidae]

Tenthredo arcuata Forster, 1770: 13. Nomen nudum.

Tenthredo arcuata Forster, 1771b: 79. Type-material not located, presumed lost. ENGLAND.

Tenthredo arcuata Forster; Benson, 1940: 231-235; 1952: 127; 1959: 96, 99.

Forster's description applies to the female. This species is one of the "arcuata-schaefferi" complex and its identity has been fixed satisfactorily by Benson. 
80.

$$
\text { Arge rustica (Linnaeus) [Argidae] }
$$

Tenthredo rustica Linnaeus, 1758: 556. Type-material not located, presumed lost. EUROPE.

Tenthredo atrata Forster, 1770: 13. Nomen nudum.

Tenthredo atrata Forster, 1771b: 80. Type-material not located, presumed lost. ENGLAND.

Arge rustica (Linnaeus); Malaise \& Benson, 1934: 4. Synonymy of atrata with rustica.

Forster's name was used for this species until Malaise \& Benson (1934) identified it as Linnaeus's Tenthredo rustica.

81.

$$
\text { Ichneumon primatorius Forster [Ichneumonidae] }
$$

Ichneumon primatorius Forster, 1770: 14. Nomen nudum.

Ichneumon primatorius Forster, 1771b: 81. Holotype [\%] not located, presumed lost. ENGLAND.

This species has been satisfactorily identified (e.g. Perkins, 1960: 173) and Forster's description fits certain female specimens perfectly.

Ichneumon is used here in the sense of Opinion 159 (1945) of the International Commission on Zoological Nomenclature.

82.

$$
\text { Amblyteles armatorius (Forster) [Ichneumonidae] }
$$

Ichneumon armatorius Forster, 1770: 14. Nomen nudum.

Ichneumon armatorius Forster, 1771b: 82. Holotype $\delta$, ENGLAND (Linn. Soc., London) [examined].

Ichneumon fasciatorius Fabricius, 1775: 330. Lectotype đ, ENGLAND, by designation of Townes, Momoi \& Townes, 1965: 502 (Univ. Zool. Mus., Copenhagen) [not examined]. Synonymized with armatorius by Marshall, 1870: 7.

Ichneumon dimicatorius Gmelin, 1790: 2680. Replacement name for Ichneumon armatorius Forster.

Ichneumon fasciatorius is type-species of Amblyteles Wesmael. Forster's species has been correctly interpreted.

83.

Ichneumon xanthorius Forster [Ichneumonidae]

Ichneumon xanthorius Forster, 1770: 14. Nomen nudum.

Ichneumon xanthorius Forster, 1771b: 83. Holotype 9, ENGLAND (Linn. Soc., London) [examined]. 
This species has been correctly interpreted.

Ichneumon is used here in the sense of Opinion 159 (1945) of the International Commission on Zoological Nomenclature.

84.

$$
\text { Exetastes atrator (Forster) [Ichneumonidae] }
$$

Ichneumon atrator Forster, 1770: 14. Nomen nudum.

Ichneumon atrator Forster, 1771b: 84. Holotype \&, ENGLAND (Linn. Soc., London) [examined].

Ichneumon cinctipes Retzius in Degeer, 1783: 68. Type-material presumed destroyed, [SWEDEN] . syn. nov.

Ichneumon obscurator Gmelin, 1790: 2687. Replacement name for Ichneumon atrator Forster.

Exetastes atrator (Forster); Marshall, 1872: 64.

Exetastes cinctipes (Retzius); Thomson, 1897: 2414.

Exetastes cinctipes (Retzius); Morley, 1908: 291. Suggested synonymy with atrator.

The holotype of atrator is labelled "I. atrator NS" [in Forster's handwriting]. It lacks the head and the hind tarsi and parts of other legs.

85.

?Phytodietus polyzonias (Forster) [Ichneumonidae]

Ichneumon polyzonias Forster, 1770: 14. Nomen nudum.

Ichneumon polyzonias Forster, 1771b: 85. Type-material not located, presumed lost. ENGLAND.

Phytodietus polyzonias (Forster); Brischke, 1864: 196.

Phytodietus polyzonius [sic] (Förster) [sic] ; Sedivý, 1961: 43.

I (M.G.F.) am not entirely satisfied that this name is correctly applied to a species of Phytodietus. None of the male specimens I have seen agrees entirely with Forster's description. However, I have seen no other British species which better fits the description. For the present it seems best to maintain existing usage.

86.

\section{Cerceris arenaria (Linnaeus) [Sphecidae]}

Sphex arenaria Linnaeus, 1758: 571. Holotype $\%$, SWEDEN (Linn. Soc., London) lexaminedl.

Sphex xanthocephala Forster, 1770: 14. Nomen nudum.

Sphex xanthocephala Forster, 1771b: 86. Holotype $\delta$, ENGLAND (Linn. Soc.,

London) [examined] . Synonymy by Morice, 1914: 286.

Dalla Torre (1897: 491) suggested that Forster's species might be a senior synonym of Philanthus triangulum (Fabricius). Morice resolved the identity of 
Forster's species in 1914, but his conclusions appear to have escaped the attention of subsequent workers. Van der Vecht (1959: 67) concurred with Dalla Torre's opinion. A single male C. arenaria in the Linnaean collection, bearing a Forster label "Sphx. xanthocephala", fits Forster's description perfectly, and confirms Morice's synonymy. Previous authors were doubtless confused by the reference to a trifid macula on the frons; in fact Forster was referring to the whole face rather than the frons in the modern sense.

87.

$$
\text { Nysson spinosus (Forster) [Sphecidae] }
$$

Sphex spinosa Forster, 1770: 14. Nomen nudum.

Sphex spinosa Forster, 1771b: 87. Holotype ơ, ENGLAND (Linn. Soc., London) [examined].

Nysson spinosus (Forster); Latreille, 1805: 305. (Latreille attributed the species to Fabricius).

This species has always been correctly interpreted. The headless type specimen has some mould on the thorax, but is readily recognizable.

88.

Chrysis cyanochrysa Forster nomen dubium [Chrysididae]

Chrysis cyanochrysa Forster, $1771 \mathrm{~b}: \mathbf{8 8}$. Type-material not located, presumed lost. SPAIN.

?Chrysis taczanowszkyi Radoszkowski; du Buysson, 1896: Appendix, 17. Suggested synonymy.

There is no specimen in the Linnaean collection. Van der Vecht (1959: 68) reiterated du Buysson's suggested synonymy.

89.

Stilbum cyanurum (Forster) [Chrysididae]

Chrysis cyanura Forster, 1771b: 89. Holotype ?? (sex uncertain), SPAIN (Linn. Soc., London) [examined]. Stilbum cyanurum (Forster); Mocsáry, 1889: 190.

This species has always been correctly interpreted since Mocsáry, 1889. The type-specimen is in good condition.

90.

\section{Stizus ruficornis (Forster) [Sphecidae]}

Vespa ruficornis Forster, 1771b: 90 . Type-material not located, presumed lost. SPAIN.

Bembex ruficornis Fabricius, 1787: 286. Syntypes 2 \& 2 o, SPAIN (Univ. Zool. Mus., Copenhagen) [not examined]. Synonymy by Van der Vecht, 1959: 68. 
Vespa gaditana Gmelin, 1790: 2765. Replacement name for Vespa ruficornis Forster.

Stizus ruficornis (Forster); Van der Vecht, 1959: 68.

There is no specimen in the Linnaean collection; Van der Vecht argued very convincingly with regard to the identity of this species.

91.

$$
\text { Agapostemon sericeus (Forster) [Halictidae] }
$$

Apis sericea Forster, 1771 a: 30 . Nomen nudum.

Apis sericea Forster, 1771b: 91. Holotype o, U.S.A. (Linn. Soc., London) [examined].

Halictus radiatus Say, 1837: 394. Type-material not located, presumed lost.

U.S.A. Roberts (1972: 520) lists further synonyms. syn. nov.

Van der Vecht (1959: 69) suggested that this bee was an Agapostemon, but thought it might be $A$. virescens (Fabricius). Roberts (1972: 554) listed the name as a nomen dubium in Agapostemon. The holotype male, though lacking forewings and hind legs, is clearly the species known as $A$. radiatus. Despite the loss of the hind legs, it is identifiable with Roberts's key, since Forster says "Femora postica dente parvo". It compares well with specimens in the British Museum collections determined by Sandhouse and by Knerer.

92.

Nomada vesparia (Gmelin) nomen dubium [Anthophoridae]

Apis vespiformis Forster, 1771a: 30. Nomen nudum.

Apis vespiformis Forster, 1771b: 92. Type-material not located, presumed lost.

U.S.A. and GERMANY. Junior primary homonym of Apis vespiformis Scopoli, 1763.

Apis vesparia Gmelin, 1790: 2788. Replacement name for Apis vespiformis

Forster.

Nomada vespiformis (Forster); Dalla Torre, 1896: 372.

This name has not yet been placed; in the absence of material, it is better to leave its application to specialists in the group.

93.

Scolia noveboracensis (Forster) comb. nov. [Scoliidae]

Apis noveboracensis Forster, 1771a: 30. Nomen nudum.

Apis noveboracensis Forster, 1771b: 93. Type-material not located, presumed lost. U.S.A., New York.

Scolia bicincta Fabricius, 1775: 356. Type-material uncertain, U.S.A. (Univ. Zool. Mus., Copenhagen), teste Bradley, 1964: 10 [not examined]. syn. nov.

Van der Vecht (1959: 70) suggested that Forster's species was a scoliid, since Forster referred to a figure of Campsomeris plumipes (Drury). Vecht concluded 
that Campsomeris dorsata (Fabricius) was the species most likely to have been described by Forster, although it neither agrees with the description, nor is found in the type locality, New York. I (M.C.D.) cannot agree with his conclusion. There seems to be every probability that this species is a scoliid, but not of the genus Campsomeris. In fact, in the North American fauna, the description applies perfectly to the species known as Scolia bicincta Fabricius, and to no other. $S$. bicincta does occur in the vicinity of New York.

There is some doubt as to the authenticity and status of Fabrician specimens of S. bicinta but this has no bearing on the valid name of the species here considered.

Drury published the first volume of his Illustrations of Natural History in 1770 , but without naming the taxa treated. Names were provided in an index to volume 1 , which was included in volume 2,1773 . Thus $C$. plumipes must date from 1773, not 1770 as usually recorded. At the time Forster published $A$. noveboracensis, Drury's species was without a name. The synonymy should thus be written as follows:

Campsomeris plumipes (Drury, 1773)

- Drury, 1770: 104, plate XXXIV, figure 5.

[Apis noveboracensis var. Forster, 1771b: 93. Misidentification.]

Sphex plumipes Drury, 1773: index to volume 1, 1770. Type-material not located, presumed lost. U.S.A., New York.

94.

\section{Melecta albifrons (Forster) [Anthophoridae]}

Apis albifrons Forster, 1771b: 94. LECTOTYPE \%, ENGLAND (Linn. Soc., London), here designated by M. C. Day [examined] .

Apis punctata Fabricius, 1775: 385. Syntypes ${ }^{\circ}$, ENGLAND (Univ. Zool. Mus., Copenhagen) [not examined] syn. nov.

Forster described from English, Spanish and German specimens. In the Linnaean collection are a male of the species known as Melecta punctata (Fabricius) (det. O. W. Richards, G. Else) bearing a Forster label "Apis albifrons var anglicana", and a female Thyreus bearing a label "Apis albifrons var hispanica". A second Thyreus bears no label, and may not be a Forster specimen. I (M.C.D.) have labelled and here designate as lectotype of Apis albifrons the male $M$. punctata from England, since the name has always been thought to apply in this genus as a synonym of $A$. luctuosa Scopoli, 1770. This latter species is much less common than $M$. punctata in England, having a southerly distribution. Indeed, since Forster's specimen is probably from Warrington, $A$. albifrons should never have been confused with $A$. luctuosa. Richards (1935: 172) established the identity of $M$. punctata.

NOMINA NUDA AND OTHER UNAVAILABLE NAMES IN HYMENOPTERA

Apis lamii Forster, 1770: 13. Nomen nudum.

Apis pennipes Forster, 1770: 13. Nomen nudum. 
Apis pennipes Linnaeus in Kirby, 1802: 297. Described in the synonymy of $A$. retusa Linnaeus. Unavailable name.

Kirby attributed this name to Linnaeus, and published a manuscript diagnosis of Linnaeus's. He was unaware that the diagnosis was based on a Forster specimen (now in Burlington House), or that he had utilized Forster's nomen nudum. Forster had described $A$. pennipes in his manuscript sent to Linnaeus.

Apis vernalis Forster, 1770: 13. Nomen nudum.

Apis vernalis Forster; Kirby, 1802: 275. Mention in synonymy.

Apis hispanica Linnaeus in Kirby, 1802: 305. Holotype \&, SPAIN (Linn. Soc.,

London) [examined] . Junior primary homonym of $A$. hispanica Fabricius, 1787.

The specimen in the Linnaean collection is a sphecid wasp, Tachytes freygessneri Kohl.

Ichneumon aterrimus Forster, 1770: 14. Nomen nudum.

\section{FORSTER COLEOPTERA AND DIPTERA}

Material labelled with the following, published, Forster names has been noted in the Linnaean collection. This list is not exhaustive. The numbers refer to Forster's Centuria (1771b).

\author{
Coleoptera \\ 1. Scarabaeus excavatus \\ 3. Scarabaeus hudsonias (label only) \\ 12. Cistela fasciata \\ 13. Cistela pustulata \\ 14. Cistela nigra \\ 15. Cistela striata \\ 16. Cistela sericea \\ 17. Silpha noveboracensis \\ 20. Chrysomela hyperici \\ 21. Chrysomela rhoi
}
23. Chrysomela olivacea
28. Chrysomela crataegi
35. Curculio noveboracensis
43. Leptura robiniae
44. Leptura pilosa
50. Cantharis americana
62. Meloe cinereus

Diptera

98. Musca melanopyrrha

100. Tabanus americanus

\section{ACKNOWLEDGEMENTS}

The Council of the Linnean Society and Mr T. O'Grady facilitated access to the Linnaean collections and library. Dr R. Fennah gave considerable help with the translation from Latin of manuscript letters; Dr W. T. Stearn drew our attention to recent biographical works. Our colleagues Dr Z. Boukek, Mr G. Else, Mr J. Quinlan and Prof. O.W. Richards gave us the benefit of their opinions as variously acknowledged in the text.

\section{REFERENCES}

BENSON, R. B., 1940. A new British Tenthredo of the arcuata-schaefferi complex, with a key to the European species (Hym. Symphyta). Entomologist's Monthly Magazine, 76: 231-5.

BENSON, R. B., 1952. Symphyta. Section (b). Handbooks for the Identiflcation of British Insects, $6(2 b):$ 51-137. 
BENSON, R. B. 1959. Revision of the European sawflies of the Tenthredo arcuata-schaefferi complex (Hymenoptera: Tenthredinidae). Proceedings of the Royal Entomological Society of London, (B), 28: 93-102.

BRADLEY, J. C. 1964. The Fabrician types of Scoliidae (Hymenoptera). Spolia zoologica Musei hauniensis, $21: 37 \mathrm{pp}$.

BRISCHKE, C. G. A., 1864. Die Hymenopteren der Provinz Preussen. Schriften der Physikalischökonomischen Gesellschaft zu Königsberg, 5: 177-212.

BUYSSON, R. du, 1896. In E. André, (Ed.), Species des Hyménoptères d'Europe \& d'Algérie, Part 11 : 705-766 + 1-22. Paris.

DALLA TORRE, C. G. de, 1896. Catalogus Hymenopterorum, 10: viii +643 pp. Lipsiae.

DALLA TORRE, C. G. de, 1897. Catalogus Hymenopterorum, 8: viii + 749 pp. Lipsiae.

DALLA TORRE, C. G. de, 1898. Catalogus Hymenopteronum, 5: viii + 598 pp. Lipsiae.

DEGEER, C., 1783. Genera et species insectorum: 220 pp. Lipsiae.

DRURY, D., 1770. Illustrations of natural history, 1: xxvii $+130 \mathrm{pp}$. London.

DRURY, D., 1773. Illustrations of natural history, 2: vii $+90+[4]$ pp. London.

FABRICIUS, J. C., 1775. Systema Entomologiae: [32] + 832 pp. Flensburgi et Lipsiae.

FABRICIUS, J. C., 1787. Mantissa Insectorum sistens Species nuper detectas, 1: xx + 348 pp. Hafniae.

FITTON, M. G., 1976. The western Palaearctic Ichneumonidae (Hymenoptera) of British authors. Bulletin of the British Museum (Natural History) (Entomology), 32: 301-373.

FORSTER, J. R., 1770. A catalogue of British insects: $16 \mathrm{pp}$. Warrington.

FORSTER, J. R., 1771 a. A catalogue of the animals of North America: 43 pp. London.

FORSTER, J. R., 1771b. Novae species insectorum. Centuria I: viii +100 pp. London.

FORSTER, J. R., Observations made during a voyage around the World: iii + iv +649 pp. London.

FOURCROY, A. F. de (Ed.), 1785. Entomologia Parisiensis, 2: 233-544. Paris.

[GEOFFROY, E. L.], 1762. Histoire abregée des insectes qui se trouvent aux environs de Paris, 2: 690 pp. Paris.

GMELIN, J. F. 1790. In C. Linnaeus, Systema Naturae, 13 th ed. 1 (5): 2225-3020. Lipsiae.

HOARE, M. E., 1971. Johann Reinhold Forster (1729-1798). Problems and sources of biography. Journal of the Society for the Bibliography of Natural History, 6: 1-8.

HOARE, M. E., 1976a. 'Ulysses' or 'incubus'? J. R. Forster's first period in England, 1766-1772. Journal of the Society for the Bibliography of Natural History, 7: 325-383.

HOARE, M. E., 1976b. The tactless philosopher, Johann Reinhold Forster. Melbourne: Hawthorn Press. KIRBY, W., 1802. Monographia Apum Angliae, 2: 388 pp. Ipswich.

KONOW, F. W., 1905. In P. Wytsman (Ed.), Genera Insectorum, Fasc. 29 (Tenthredinidae): 176 pp. Bruxelles.

LATREILLE, P. A., 1805. Histoire naturelle, générale et particuliére, des Crustacés et des Insectes, 13: 432 pp. Paris.

LINNAEUS, C., 1758. Systema Naturae, 10th ed. 1: 823 pp. Holmiae.

MALAISE, R. \& BENSON, R. B., 1934. The Linnean types of sawflies (Hymenoptera, Symphyta). Arkiv fór zoologi, 26(20): 1-14.

MARSHALL, T. A., 1870. Ichneumonidum Britannicorum Catalogus: 22 pp. London.

MARSHALL, T. A., 1872. A catalogue of British Hymenoptera; Chrysididae, Ichneumonidae, Braconidae and Evaniidae: viii $+136 \mathrm{pp}$. London.

MARSHAM, T., 1802. Coleoptera Britannica: xxxi + 548 pp. London.

MOCSÁRY, A., 1889. Monographia Chrysididarum orbis terrarum universi: xv + 643 pp. Budapest.

MORICE, F. D., 1914. What was Sphex xanthocephala Forster (a British insect, but ignored in British Lists)? Entomologist's Monthly Magazine, 50: 286-288.

MORLEY, C., 1908. Ichneumonologia Britannica, 3: xvi + 328 pp. London.

OPINION 159, 1945. On the status of the names Ephialtes Schrank, 1802, Ichneumon Linnaeus, 1758 , Pimpla Fabricius [1804-1805], and Ephial tes Gravenhorst, 1829 (Class Insecta, Order Hymenoptera). Opinions rendered by the International Commission on Zoological Nomenclature, 2: 275-90.

PERKINS, J. F., 1960. Ichneumonidae, subfamilies Ichneumoninae II, Alomyinae, Agriotypinae and Lycorininae. Handbooks for the identification of British Insects, 7(2aii): 117-213.

RICHARDS, O. W., 1935. Notes on the nomenclature of the aculeate Hymenoptera, with special reference to British genera and species. Transactions of the Royal Entomological Society of London, 83: 143-176.

ROBERTS, R. B., 1972. Revision of the bee genus Agapostemon (Hymenoptera: Italictidae). Kansas University Science Bulletin, 49: 437-590.

SAY, T., 1837. Descriptions of new species of North American Hymenoptera and observations on some already described. Boston Journal of Natural History, 1: 361-416.

SCOPOLI, J. A., 1763. Entomologica Carniolica: [36] + $420+$ [2] pp. Vindobonae.

SCOPOLI, J. A., 1770. Annus historico naturalis, 4: 150 pp. Lipsiae.

SEDIV'Y, J., 1961. Beitrag zur Kenntnis der Tryphoninen-Gattungen Phytodietus Grav. und Weista Schmdkn. (Hymenoptera, Ichneumonidae). Časopis. Československé spolę̌nosti entomologické, 58: 37-44. 
SHILLITO, J. F., 1976. Fothergill and Linnaeus. The background of De Bigis Insectorum, 1775. Biological Journal of the Linnean Society, 8: 75-86.

THOMSON, C. G., 1897. Opuscula entomologica, 22: 2405-2452. Lund.

TOWNES, H., MOMOI, S. \& TOWNES, M., 1965. A catalogue and reclassification of the eastern Palaearctic Ichneumonidae. Memoirs of the American Entomological Institute, 5: v +661 pp.

VECHT, J. van der, 1959. Notes on aculeate Hymenoptera described in the period 1758-1810. Entomologische Berichten, 19: 65-70. 